\title{
Encroachment of the Buriganga River in Bangladesh
}

\author{
Swarnali Mahmood1, Fatema Tuz Johra Nourin'1, Ayesha Siddika1', Tazeen Fatima Khan ${ }^{2 *}$ \\ ${ }^{1}$ Institute of Water and Flood Management, Bangladesh University of Engineering and Technology, Dhaka, Bangladesh \\ ${ }^{2}$ Department of Soil, Water and Environment, University of Dhaka, Dhaka, Bangladesh \\ Email: ^tazeenkhan18@du.ac.bd
}

How to cite this paper: Mahmood, S., Nourin, F.T.J., Siddika, A. and Khan, T.F. (2017) Encroachment of the Buriganga River in Bangladesh. Journal of Minerals and Materials Characterization and Engineering, 5, 266-273.

https://doi.org/10.4236/jmmce.2017.55022

Received: April 29, 2017

Accepted: August 18, 2017

Published: August 21, 2017

Copyright $\odot 2017$ by authors and Scientific Research Publishing Inc. This work is licensed under the Creative Commons Attribution International License (CC BY 4.0).

http://creativecommons.org/licenses/by/4.0/

\begin{abstract}
A survey on different aspects of Buriganga River encroachment was conducted in a 300 meter long encroached part of the river located in Dhaka, Bangladesh. A total of 100 respondents were surveyed and three Focus Group Discussions (FGDs) were arranged prior to the semi-structured questionnaire survey. It was observed that almost all of the respondents migrated to the study area. The majority of the respondents had better business opportunity (69.23\%) as the cause of encroachment. Significant portions of the respondents occupying the encroached area were found to be landless (36.84\%), small businessmen $(31.58 \%)$ and people with political affluence $(26.32 \%)$. Major portions (23.33\%) of the encroached land were used for industrial development as well as housing and developmental projects. Negative health impact (40\%) was found to be the main adverse effect of encroachment of the river. Other adverse effects included economic loss through obliteration of fisheries $(35.71 \%)$, scarcity of clean water $(32.14 \%)$, reduction of aesthetic value of the surroundings (25\%) etc. For the protection of the river, the majority of the respondents opted for relocation of the industries (46.15\%) and enforcement of strict rules and regulations $(38.46 \%)$.
\end{abstract}

\section{Keywords}

Buriganga River, Encroachment, Respondents, Questionnaire Survey

\section{Introduction}

The Buriganga River, which demarcates the southwest extent of Dhaka City, is one of the most polluted rivers in Bangladesh [1]. This river has become biologically and hydrologically dead because of the indiscriminate dumping of domestic and industrial wastes as well as encroachment by the unscrupulous people [2]. 
Most of the industries and factories of Dhaka are mushroomed on the bank of the Buriganga or very close to the river system without setting up proper waste treatment units during the past decades. The urban sewage of Dhaka city is also thrown in the river. As a result, sedimentation and drying up of the river is aggravated with huge amount of effluents and solid wastes [3].

Encroachment is the primary cause for demolishing the bank of the Buriganga River which ultimately leads to narrowing of the river. Over the years, landfills created on the bank of the river have narrowed its width [4]. Furthermore, the encroachers build platform-like structures and fill out the bottom with soil and city garbage, and then gradually build multistoried structures over them [5]. Both severe environmental deterioration and economic growth retardation have been taking place because of this [6]. However, the river can be revived if adequate steps are taken immediately to check the encroachment. Considering these aspects, the present study was undertaken to investigate the present status of the Buriganga River encroachment along with its causes and effects and some feasible measures to protect the river.

\section{Materials \& Methods}

The study intended to explore the scenarios of encroachment around the river Buriganga that encompasses the south-western periphery of Dhaka City. To satisfy the objective, an approximate area of 300 meters between Babu-Bazar Boat Terminal and Mitford Ghat with permanent or temporary establishments of one row form the bank line of Buriganga River was selected as the study area.

Both qualitative and quantitative data were collected from primary and secondary sources for conducting the present study. Primary data were collected by field investigation through Focus Group Discussions (FGDs) followed by semi-structured questionnaire survey. The selected target group was the land users on the bank of the river. A non-probability purposive sampling technique was applied following the method as described in [7] for the questionnaire survey due to the unknown population size and limited time horizon. Field visits were made prior to the questionnaire survey for pilot survey of the study area and for conducting FGDs in order to refine the questionnaire required for the final survey.

A semi-structured questionnaire containing ten questions was prepared by the surveyors. A total of 100 land users living on bank of the river were surveyed. Also, the data related to the demographics of the survey respondents including residence status, duration of residence in the region, gender, age etc. were collected. The results of the study were analyzed using Microsoft Excel.

\section{Results \& Discussion}

\subsection{Demographics of the Respondents}

The origin of all the respondents was found to be outside of Dhaka City (Table 1) which indicated high rate of migration in the study area. The increased 
Table 1. Demographic information of the respondents in the study area.

\begin{tabular}{ccc}
\hline Parameter & Demographic information & Percentage \\
\hline \multirow{2}{*}{ Gender } & Male & $88 \%$ \\
& Female & $12 \%$ \\
Ownership Pattern & Tenant & $26 \%$ \\
Origin & None (Illegal temporary ownership) & $74 \%$ \\
& Out of Dhaka & $100 \%$ \\
Level of Education & Illiterate & $14 \%$ \\
& Primary & $67 \%$ \\
Land Possession & SSC & $19 \%$ \\
\hline
\end{tabular}

population pressure due to migration seemed responsible for land encroachment. It was revealed through FGDs that selling or renting of the encroached land in cheap price worsened the situation. The respondents consisted of varying age group ranging from 15 to greater than 55 years who hardly possessed educational qualification up to SSC level and some were even illiterate. Lack of proper education seemed one of the reasons for river encroachment.

\subsection{Causes of Encroachment}

From Table 1 it is clear that all of the respondents were migrants. Figure 1 shows that most of the people migrated in the study area for better business opportunity $(69.23 \%)$. The other benefits were associated with low cost of land (15.38\%), low house rent (7.69\%) and proximity of the residence to the workplace (7.69\%). FGDs also revealed that the encroached lands were low lying and more vulnerable to natural and anthropogenic disasters, and for that, both the land cost and rent were low. Therefore, migrated people could avail the encroached land parcels easily for business and/or for dwelling. These benefits instigated and accelerated the land encroachment process.

\subsection{People Involved in Encroachment}

It was observed that majority of the population do not morally support the trend of river encroachment, although they were actively and/or passively responsible for the encroachment.

Figure 2 reveals that the majority of the respondents who occupied the encroached land were the landless people (36.84\%). The migrated people mostly consisted of the landless people of the study area. Other significant encroachers included small businessmen (31.58\%) and the people with political affluence (26.32\%). The minor occupiers were the brick and sand traders (5.26\%). This entire encroacher category depicted the poor law enforcement scenario. 


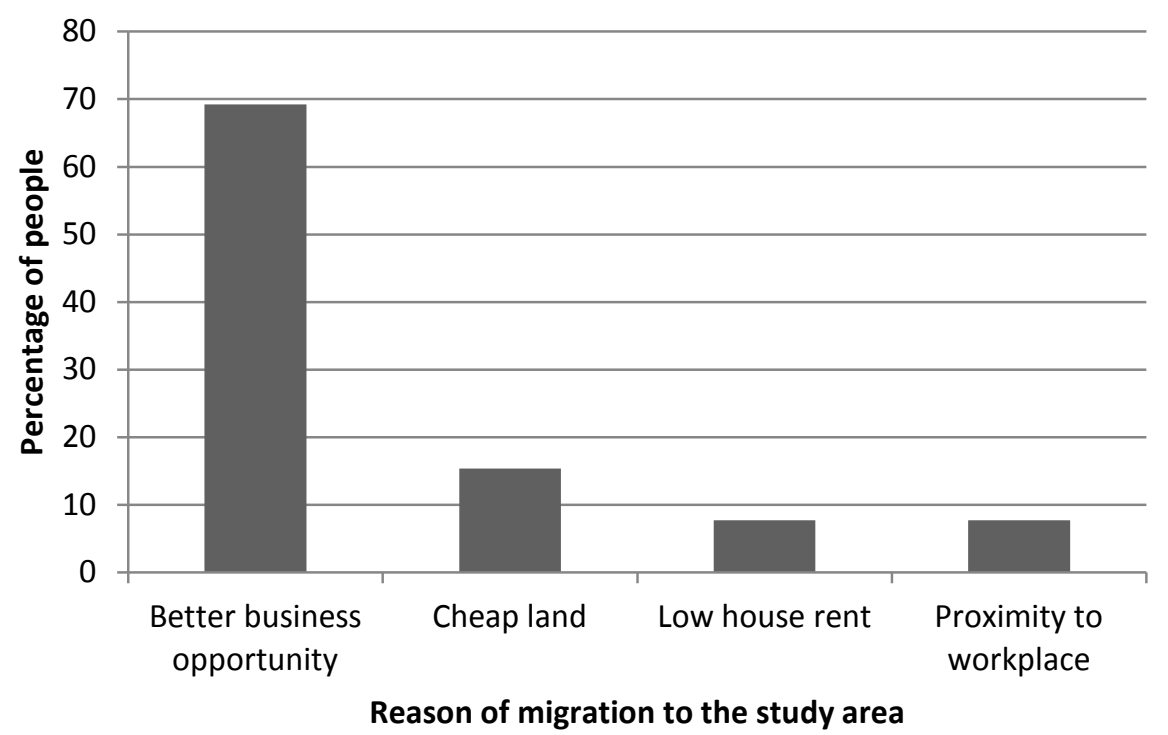

Figure 1. Reason of migration to the study area.

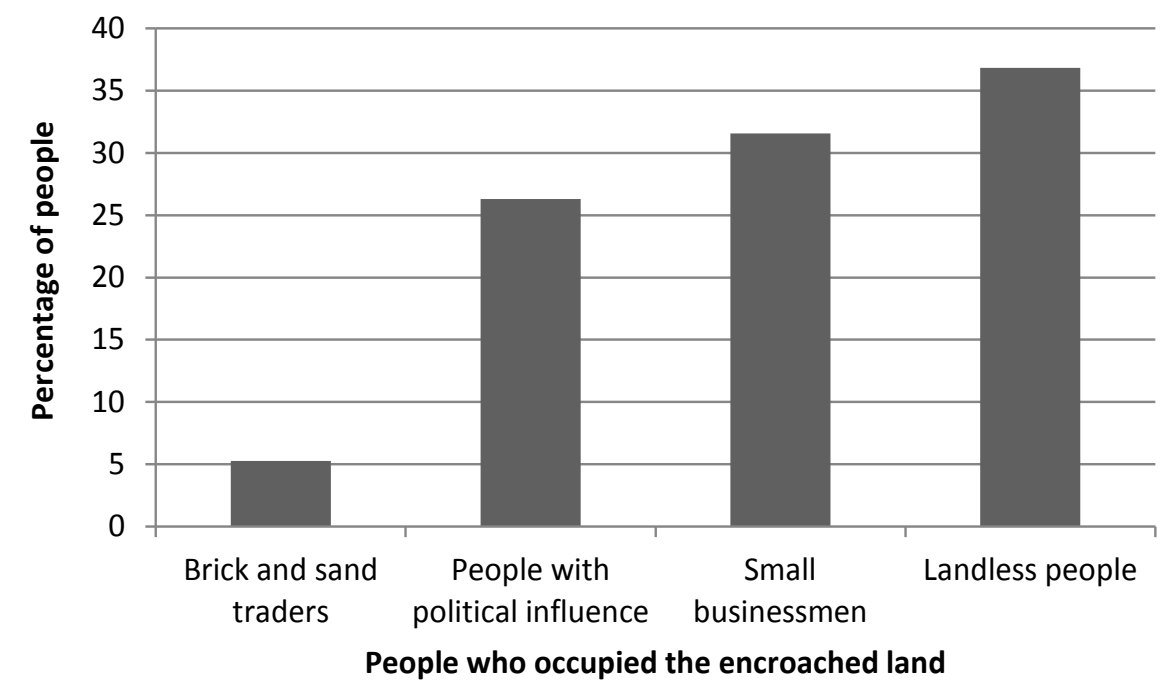

Figure 2. People who occupied the encroached land.

\subsection{Establishments over the Encroached Areas}

Figure 3 illustrates the percentage of present use of encroached land in the study area. The study found that major portion (23.33\%) of the encroached land was being used for industrial development as well as housing and developmental projects through land filling. These land uses could have remained as part of the river if it was possible to stop encroachment.

\subsection{Impacts of Encroachment on the Environment}

It was revealed that Buriganga River encroachment exerts a number of negative impacts (Figure 4) on the surrounding environment including hindrance of natural flow of river, water pollution, adverse impact on public health, impact on ecosystem, etc. The study found that the main adverse effect of river encroach- 


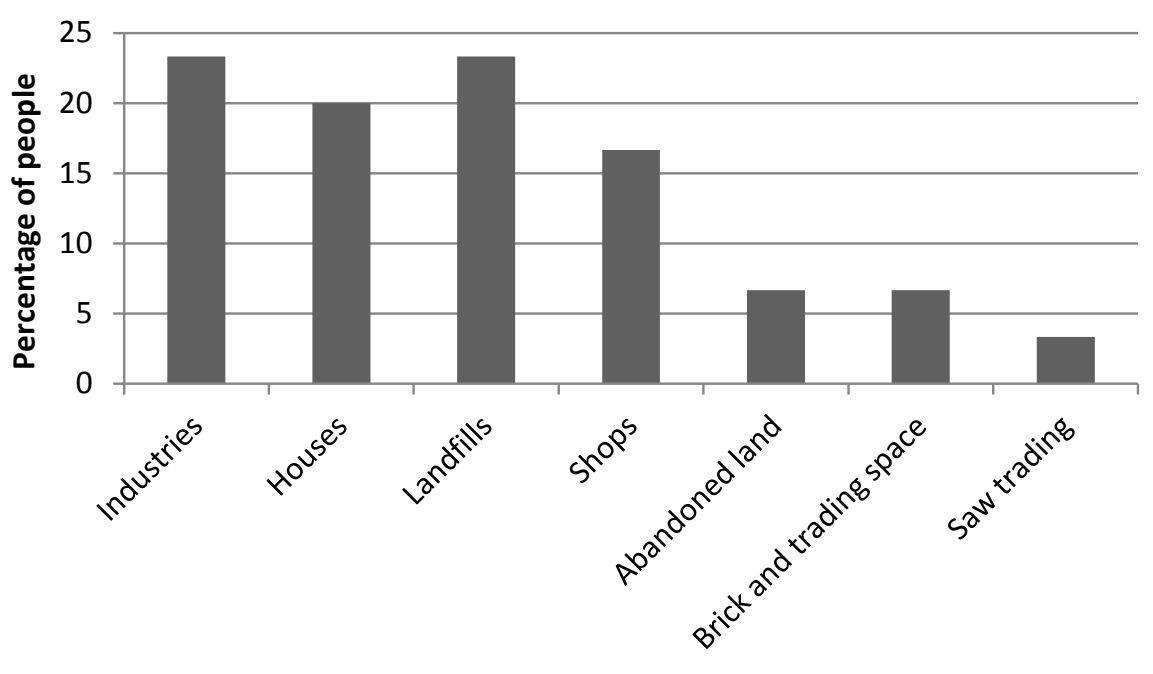

Present use of encroached land

Figure 3. Present use of encroached land.

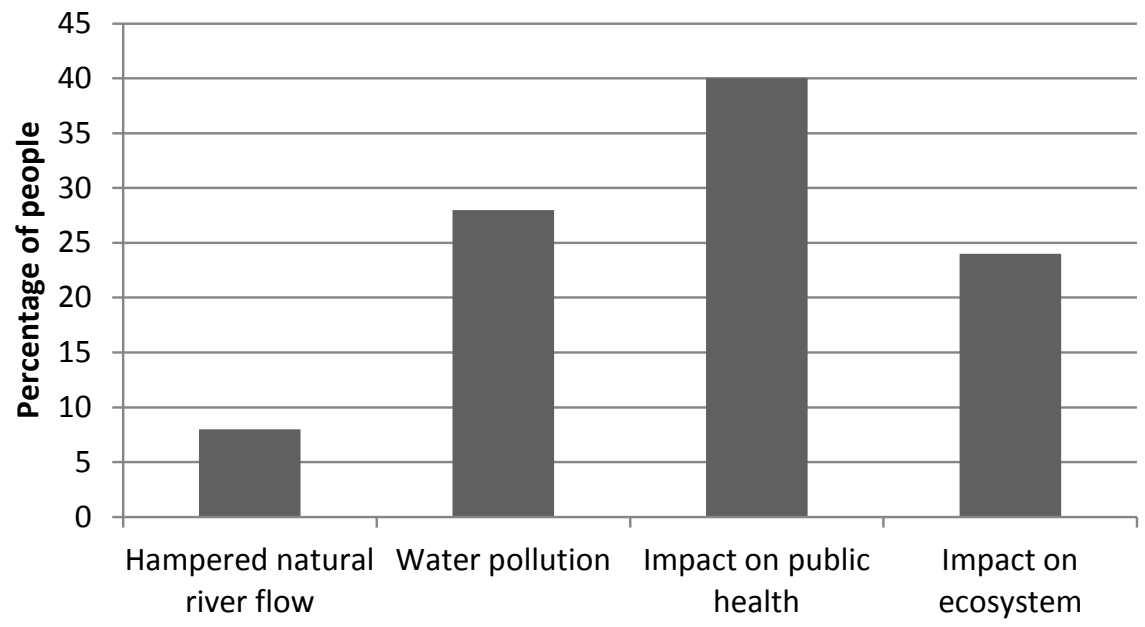

Impact of encroachment on the surrounding environment

Figure 4. Impact of encroachment on the surrounding environment.

ment is the negative health impact of the people living in the surrounding area (40\%) as the encroached lands are achieved mostly through landfilling with urban wastes. Significant portion of the respondents also stated that pollution of water $(28 \%)$ as well as hampering of ecosystem (24\%) is the adverse impacts of encroachment. Buriganga River water is not safe for drinking purpose, irrigation, fisheries, and various industrial uses for most of the times of a year [8] [9]. The level of pollution in dry season is much higher compared to that of the wet season [3].

\subsection{Impacts of Encroachment on the Economy}

The present study found several economic losses due to river encroachment in the Buriganga (Figure 5). Obliteration of fisheries (35.71\%), scarcity of clean water (32.14\%) and hampering the aesthetic value of the surroundings (25\%) 


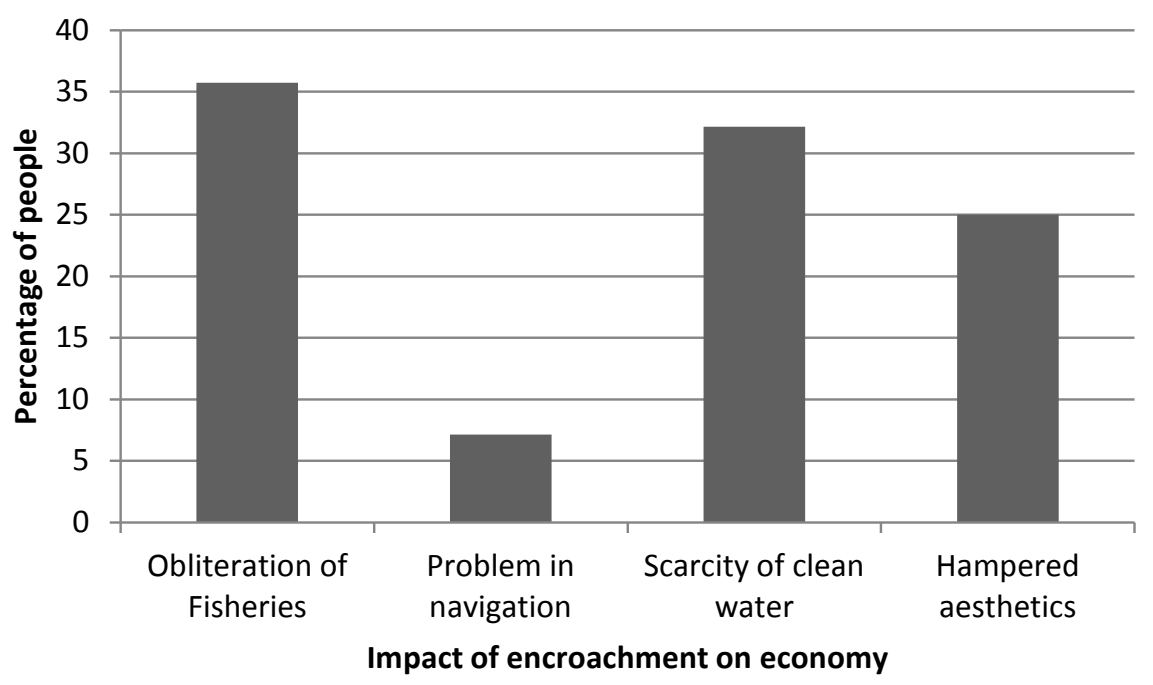

Figure 5. Impact of encroachment on economy.

contributed to the major portion of economic losses. As environmental protection and economic development concepts and reality are interrelated and inseparable [10], government-community-private sector partnerships for restoring the ecological health of the river is much needed.

\subsection{Remedial Measures}

It is vital for the country to protect, restore and preserve the Buriganga River and its watershed environment through Environmental Conservation Actions. According to the respondents, the most important steps to curb encroachment are to relocate the industries (46.15\%) and to enforce strict laws and regulations (38.46\%) (Figure 6). Political and economic problem is the main factor constraining the efforts of government organizations, departments and agencies due to ill-conceived and implemented policies and programs, corruption and poor governance, often aggravating the situation [6]. Besides, isolated efforts by various non-government and civic movement organizations are also inadequate to cope with the present crisis [6].

It is a huge task to reform land management laws to recover thousands of acres of land inside the river Buriganga [11]. The Government enacted a law named "Water Body Act, 2000" and constituted a taskforce to save the Buriganga. The Hazaribagh Tannery Relocation Project (HTRP) was undertaken by the Ministry of the Industries in 2003 to save the capital city and the Buriganga River from toxic pollution under which all tannery industries would be relocated to Savar from the city's Hazaribagh area and waste treatment plants would be set up to save the environment from further pollution [12]. As a temporary measure, BIWTA has planned to reach the reclaimed land on the Buriganga banks from Fatullah to Shyambazar for economic activities on an annual contract basis to wholesale rice, fruits and vegetables traders, and as a permanent measure, BIWTA plans to construct three to four foot wide brick walkways on both sides 


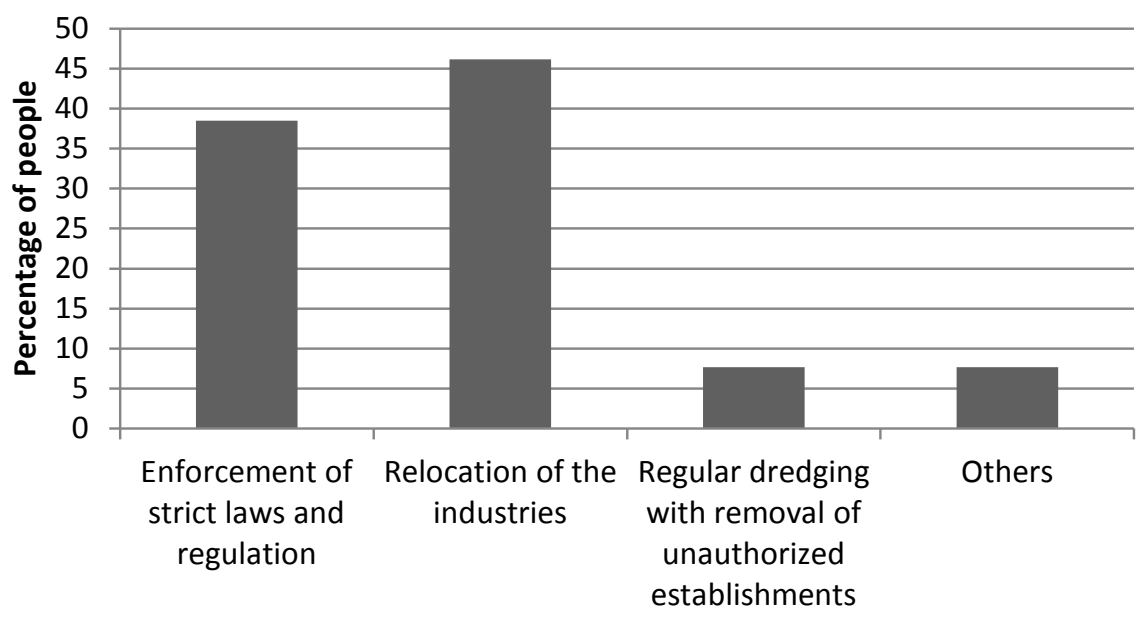

Remedial measures to reduce encroachment

Figure 6. Remedial measures to reduce encroachment.

of the river and recreational facilities for tourists and for locals also and walls to protect the river and plant trees [13].

\section{Conclusion}

Protection and management of the Buriganga River have been a great challenge at present. Encroachment of this river is one of the burning questions of today's modern world. Encroachment is done with an intention of more profit in trade and business. Numerous private land development activities, housing projects, industrial development as well as landfilling contributes to a large extent towards the encroachment process. Encroachment possesses great threat to our surrounding environment which leads to degraded ecosystem, poor economy as well as poor public health. Key strategy for controlling the encroachment must be based on the principles of Environmental Conservation Actions. Both Government and Non-Governmental Organizations (NGOs) must come forward by taking necessary measures to control the encroachment or to minimize the harmful impacts of it. This encroachment ultimately leads to increased protection and restoration of the river. Further detailed study is needed with more encroached areas of the river to get overall situation of the river encroachment.

\section{Acknowledgements}

The authors would like to thank the respondents of the survey for providing necessary information. Without their cooperation this work would not have been possible.

\section{References}

[1] Kamal, M.M., Hansen, A.M. and Badruzzaman, A.B.M. (1999) Assessment of Pollution of the River Buriganga, Bangladesh, Using a Water Quality Model. Water Science and Technology, 40, 129-136.

[2] Ahmed, A.U. and Reazuddin (2000) Industrial Pollution of Water Systems in Ban- 
gladesh. University Press Limited, Dhaka, 175-178.

[3] Moniruzzaman, M., Elahi, S.F. and Jahangir, M.A.A. (2009) Study on Temporal Variation of Physico-Chemical Parameters of Buriganga River Water through GIS (Geographical Information System) Technology. Bangladesh Journal of Scientific and Industrial Research, 44, 327-334.

[4] Alam, M.K. and Marinova, D. (2003) Valuing Benefits of Environmental Improvement: The Case of the Buriganga River in Bangladesh. Proceedings of the International Summer Academy on Technology Studies. Technology and the Public, Deutschlandsberg, 7-13 July 2002, 169-176.

[5] Islam, M.S., Rahman, M.R., Shahabuddin, A.K.M. and Ahmed, R. (2010) Changes in Wetlands in Dhaka City: Trends and Physico-Environmental Consequences. Journal of Life and Earth Science, 5, 37-42.

[6] Biswas, B. and Hamada, T. (2013) Political Economic Problem for Environmental Conservation of River Buriganga in Bangladesh. International Journal of Environment, 3, 28-38.

[7] Boateng, W. (2012) Evaluating the Efficacy of Focus Group Discussion (FGD) in Qualitative Social Research. International Journal of Business and Social Science, 3, 156-175.

[8] Chakraborty, C., Huq, M.M., Ahmed, S., Tabassum, T. and Miah, M.R. (2013) Analysis of the Causes and Impacts of Water Pollution of Buriganga River: A Critical Study. International Journal of Science and Technology Research, 2, 245-252.

[9] Rahman, M.A. and Bakri, D.A. (2010) A Study on Selected Water Quality Parameters along the River Buriganga, Bangladesh. Iranica Journal of Energy and Environment, 1, 81-92.

[10] Rees, W.E. (2003) Economic Development and Environmental Protection: An Ecological Economics Perspective. Environmental Monitoring and Assessment, 86, 2945. https://doi.org/10.1023/A:1024098417023

[11] Rahman, M.R. and Rana, M.Y. (1992) Management of Buriganga River Water Quality under Alternative Scenarios. Final Report, R02/95. IFCDR, BUET, Dhaka.

[12] Bhowmik, A.K. (2008) Buriganga Pollution: Reasons and Prospects. In: Planning Students' Convention, Ed., Environment and Urban Development, Urban and Rural Planning Discipline, Science, Engineering and Technology School, Khulna University, Khulna, 87-97.

[13] Mowla, Q.A. and Mozumder, M.A.K. (2015) Deteriorating Buriganga River: Its Impact on Dhaka's Urban Life. PSC Journal, 2, 1-10. 
Submit or recommend next manuscript to SCIRP and we will provide best service for you:

Accepting pre-submission inquiries through Email, Facebook, LinkedIn, Twitter, etc. A wide selection of journals (inclusive of 9 subjects, more than 200 journals)

Providing 24-hour high-quality service

User-friendly online submission system

Fair and swift peer-review system

Efficient typesetting and proofreading procedure

Display of the result of downloads and visits, as well as the number of cited articles Maximum dissemination of your research work

Submit your manuscript at: http://papersubmission.scirp.org/

Or contact jmmce@scirp.org 